\title{
Everyday Active Citizenship the Balkan Way: Local Civil Society and the Practice of 'Bridge Building' in Two Post-Yugoslav Cities
}

\begin{abstract}
Active citizenship in the post-war Western Balkans has traditionally been studied in the context of either Western-style (and usually foreign-funded) Non-Governmental Organisations (NGOs) or, more recently, protest movements. This chapter highlights a wider range of better- and lesser-known forms of civil society in the contemporary postYugoslav space. It shows how interest associations, student unions, religious groups and online communities can all contribute to vibrant civil society, even if their work seems distant from the post-war area's current problems. This civil society, the chapter argues, creates an environment in which the people of the western Balkans can enact their citizenship and, little by little, 'build bridges', across ethnic lines and beyond.
\end{abstract}

\section{Introduction}

Active citizenship, as Fuller et al. (2008) put it, 'broadly understood, can mean any form of productive contribution to society.' In the Western context, however, such 'productive contribution' has been usually seen as connected to either economic activity (ibid., I57) or engagement in the political affairs of the country (Kearns I995; Marinetto 2003). In the SouthEast European context, the issue has been mostly discussed in relation to protest movements, particularly the most recent ones in various cities of Bosnia-Herzegovina in early 2014 and in other successor states of former 
Yugoslavia and in wider South-Eastern Europe since 20II (Sardelić 2013; Štiks and Horvat 20I4).

In this chapter I look at a different type of active citizenship. I argue that active participation in local civil society ${ }^{1}$ can be considered to be a form of active citizenship, even if the sector of civil society in which a person is active is not particularly political. Or, rather, that it does not seem to be of immediate political significance when considering the notion of political in its narrow sense: related to party-politics, governance, formal projects of 'democratisation' and other endeavours of quantifiable outcomes. Considering everyday practices, this chapter engages with theories which call for appreciation of such practices, particularly the theory of micro-politics (Goldfarb 2006, 2008) and that of everyday peace (Mac Ginty 2013). It also draws close to the theory of acts of citizenship (Isin 2008) and that of vernacular cosmopolitanism (Bhabha 1996).

Jeffrey Goldfarb's theory of micro-politics stem from his study of student theatres in Poland in the late 1970 s and of the forces which eventually led to the fall of the communism in the late 1980 (Goldfarb 1980, 2006). Goldfarb argues that the political changes that happened were catalysed by a range of small and seemingly unimportant everyday behaviours and events. Meetings of individuals in spaces of political privacy, for instance by the kitchen table, and poetry events, which were condemned by communist authorities, but during which participants 'conducted themselves as they would at any cultural gathering' (Goldfarb 2006, II) were according to Goldfarb important catalysers of change. He convincingly argues that 'people acted as if they lived in a free society and a free society resulted' (ibid., 69). In the context of quite different realms and problems Roger Mac Ginty (2013) points out that for post-conflict societies, seemingly small changes, such as 'storeowners painting their storefronts' or 'the resumption of cultural practices that declined during conflict' (ibid., 56), can constitute a more

In this chapter I understand civil society in a (neo-)Tocquevillian manner, i.e. as associational life in all its richness (Tocqueville 1956). However, in places, I also refer to the understanding of civil society as the counter-balance to the state, as promoted, most notably, by Antonio Gramsci (2007). 
meaningful indicator of positive transmission than Human Development Index, Gross Domestic Product and other formal indicators.

More theoretically, Engin F. Isin distinguishes between acts and actions of citizenship (Isin 2008). 'To act [...] is neither arriving at a scene nor fleeing from it, but actually engaging in its creation. With that creative act the actor also creates herself/himself as the agent responsible for the scene created' (Isin 2008, 27). And citizenship 'involves practices of making citizens - social, political, cultural and symbolic' (ibid., I7). While acts are not practices (ibid., I8), acts and practices are strongly bound and dependent on each other. The practices which this chapter considers allow for acts of citizenship, allow for creation of scenes within which citizenship is enacted and in which under some circumstances acts can become actions.

Finally, we may perceive everyday active citizenship described in this chapter as an instance of vernacular cosmopolitanism (as defined by Bhabha 1996). Such connection however needs to be made with caution. If we take cosmopolitanism as, first of all, appreciation of (national) cultures other than our own, then calling the 'bridge building' practices in the postwar Western Balkans 'cosmopolitan' is likely to obscure the nature of these practices rather than explain them. For in the area in question, unlike in the Western Europe, 'building bridges' is often about appreciation of a local culture which has been hybrid for centuries, rather than of 'new hybridities' (Beauregard and Body-Gendrot 1999; Binnie et al. 2006), of well-known rather than of unknown (for my short discussion on this see Goldstein 2015). While Nava (2002) tells us that 'ordinariness and domestication of difference are the distinguishing marks of vernacular cosmopolitanism in urban Britain today' (ibid., 94), talking of 'domestication of difference' in Western Balkans would be inappropriate, if not for anything else, for that it would be hard to say which of the cultures would be domestifying and which domestified. However, if we consider cosmopolitanism more broadly, as appreciation of human (and not only national/ethnic) difference, then we may point out also here, within practices of Western Balkan active citizens, what Bhabha calls "vernacular cosmopolitan" negotiation [...] between the "insufficiency of the self" [...] and the needs of modern, urban communities of interest and inquiry' (Bhabha 1996). Such negotiation is an important element of the 'bridge building' which this chapter discusses. 
In this chapter I link the above theories to argue that the engagement of individuals in the (broadly understood) civil society can be seen as a sign of everyday peace, an important part of micro-politics, a field for acts of citizenship and in many instances for what can be perceived as vernacular cosmopolitanism. Or in other words, that this engagement is worth appreciating as an important step on the region's route to social and political change.

\section{Method and setting}

This chapter is based on findings of mixed-methods research conducted in Mostar, Bosnia-Herzegovina and Novi Sad, Serbia between 2010 and 20I4, within two larger research projects. The research consisted of ethnographic investigation with local civil society actors combined with 77 interviews, two questionnaire surveys distributed among both leaders and 'regular members' of associations, and photography used as a research method.

The two cities, Mostar and Novi Sad, were chosen for a range of superficial similarities that go in pair with profound dissimilarities which make them an excellent setting to explore a wide range of challenges (and opportunities) of contemporary post-Yugoslav societies. These two cities may at first seem similar: each is in a way its country's 'second city' (Novi Sad is the second biggest city in Serbia, while Mostar is the capital of Herzegovina, one of Bosnia-Herzegovina's two historical constituencies); both cities are multi-ethnic; both had important bridges destroyed during the Yugoslav wars of the I990s; both are post-industrial and both have large student populations.

However, everyday life in these cities is shaped by what makes them very different. Mostar, once multi-ethnic and cosmopolitan, has experienced all the atrocities of the recent wars. Its bridges, most notably the centuries old 'Old Bridge', were destroyed in fighting between former neighbours. The city still bears the stigma of war as it is hard to find a building, particularly in the city centre, that would not be covered in bullet 
holes, and war-time ruins are omnipresent across the city. Most importantly though, the city is divided. Bosniak and Croat populations, once evenly spread across the town now live separated by an invisible wall that runs along Bulevar - a multi-lane road which used to constitute the front line at the time of war. The two sides of the city are home to two city centres, two universities, two separate post office companies, two electricity and heat providers, etc. Citizens of Mostar sometimes smile when they say 'there is two of everything here', but for many of them this truth is deeply painful.

Novi Sad is very different. It was established in 1748 , within Habsburg Empire, as an effect of cooperation between local Hungarians and Danube Swabians and a large Serbian minority and, despite large population shifts after Second World War and throughout recent conflicts, it remains multi-ethnic. Nowadays it is home to a Serbian majority and a multitude of minorities, most notably Hungarians, but also Croats, Ruthenians, Romanians, Slovaks, Roma, Jews and others. Unlike Mostar, it was not affected by direct fighting. Its bridges were bombed, but not by locals, but by NATO, an 'external enemy'. It would be wrong however to think of Novi Sad as untouched by war - many of the city's men were incorporated in the Serbian army and the huge influx of refugees became a root of many today's conflicts. The minorities experienced 'low level violence' (Bieber and Winterhagen 2006), but this was enough for incurring long lasting resentment and mistrust.

\section{Bridge building}

During the wars of the 1990 s both Mostar and Novi Sad had important bridges destroyed. The destruction of one of them in particular - Mostar's Old Bridge - was frequently used in the Western media as a symbol representing divided communities (Bicic 1993; Sudetic 1993; Williams 1993). In the aftermath of the wars, the international community has sought to rebuild trust and dialogue across communities in order to prevent a return to the violence of the I990s. A key metaphor has been that of 'bridge 
building, and civil society was viewed as having a key role to play in this process. Civil society has been expected to foster inter-ethnic dialogue and reconciliation, and to assist in many other tasks such as promoting minority rights and gender justice, or healing psychological trauma.

The metaphor of bridges and bridge building, used by foreign media and donor institutions, was probably even more powerful on the local level. The post-1944 cultural mythology of Yugoslavia was built on the symbol of the bridge and Ivo Andrićs Nobel-winning The Bridge on the Drina (1977) was the apotheosis of Yugoslav literature. ${ }^{2}$ The bridge described by Andrić was not only a connector between places and people. It was also a witness to events important for the surrounding communities, for men and women, young and old, soldiers and civilians, educated cosmopolitans and those who have never left the town.

Another metaphor is that of the Balkans themselves as a bridge: a bridge between East and West, Eastern and Western Christianity, and the influences of Islam and the Western world. ${ }^{3}$ In this context, (re)building bridges can be equated with re-building not only the prosperity, but also the international significance of the entire region.

In the aftermath of the inter-ethnic violence which accompanied and followed the dissolution of Yugoslavia, it is easy to think of 'bridge building' in that region mostly in relation to ethnicity. However, there are also other 'bridges' that need to be built. Tensions and discrimination based on gender, age, class, sexual orientation, physical ability, or being local or a newcomer to the city, are all vivid in the region. For many young or elderly people, the generational conflict is the one that they need to face on an everyday basis. For many of the refugees and the displaced, but also for those who moved into a city for economic reasons, being looked upon as unwanted dosljaci (newcomers), supposedly more primitive than the

2 I am grateful to Dr Adelina Angusheva-Tihanov for this assertion.

3 These metaphors and their echoes were explored, for instance, by Todorova (1997) and Goldsworthy (2002). For further analysis, placed in the particular context of the destruction and rebuilding of Mostar’s Old Bridge, see Gunzburger Makaš (200I). 
'old settlers' (starosjedioci /starosedeoci) of the city, is a significant trauma. ${ }^{4}$ Thus, in this chapter I agree with Piekut et al. (2012) who advise us to 'shift the discussion on social diversity from ethnic diversity to broader social diversity'. In line with this scope, I do approach work of civil society actors that operate in the field of 'broader social diversity', and that actively are involved with 'building bridges' across various, not only ethnic, lines.

\section{Local civil society}

The literature on Western Balkan/South East European civil societies is often explicit in reducing the study of these civil societies to NGOs or, even further, to foreign-funded NGOs (see, for instance, Dević 2003, 7; Fagan 2010, 50; Kostovicova and Bojičić-Dželilović 2013, 9; Stubbs 1999, v). This is despite the fact that the authors often recognise that such reduction is problematic. One of its consequences is that, as Denisa Kostovicova and Vesna Bojičić-Dželilović put it, 'a variety of traditional grass-roots institutions, networks, practices and actors, with a potentially more constructive input towards aims of post-conflict transition have been overlooked' (Kostovicova and Bojičić-Dželilović 2013, 9). In this chapter I argue that the part of civil society which has been overlooked is in fact much more ample, and by no means less significant, than that comprised of NGOs.

$4 \quad$ Starosjedioci in Bosnian and Croatian and starosedeoci in Serbian. The tension between starosjedioci/ starosedeoci and dosljaci has been described, for instance, in Paolo Rumiz, Maschere per un massacro. Quello che non abbiamo voluto sapere della guerra in Jugoslavia (Milano: Feltrinelli Editore, 2011, 103-104) and analysed further in Jansen (2005). 


\section{(Typical) $N G O s$}

My research revealed that, at least for Mostar and Novi Sad, most people, be they foreign researchers or local activists, define NGOs in a way similar to Claire Mercer (2002). According to her review of literature on NGOs, these are:

[ $t$ ] hose organizations that are officially established, run by employed staff (often urban professionals or expatriates), well-supported (by domestic or, as is more often the case, international funding), and that are often relatively large and well-resourced. NGOs may therefore be international organizations or they may be national or regional NGOs. They are seen as different from Grassroots Organizations (GROs) that are usually understood to be smaller, often membership-based organizations, operating without a paid staff but often reliant upon donor or NGO support. (Mercer 2002, 6)

This is a rather Western definition, which would be inappropriate, for example, in Poland, where few of the NGOs are run by employed staff. However, it seems to be accurate in Mostar and Novi Sad. By accurate I mean that this definition in principle encompasses organisations which would consider themselves NGOs and that would be regarded as such, also by local and foreign donors, researchers, and other relevant players. Of course, not all Mostar and Novi Sad NGOs employ staff on a full-time basis; many of them are small and many are badly financed. However, the general idea of differentiating NGOs from GROs, and seeing the former as operating on a possibly larger budget, seems to have a large following.

While such NGOs receive a lot of academic, media and public criticism, it is wrong to think that all such associations are corrupt, inefficient, etc. Similarly, it would be naïve to perceive all other types of civil society actors (as listed below) as automatically good and possessing all the qualities that 'typical' NGOs are said to lack. What is more, there exists a multitude of definitions and some of them would consider all types of the civil society actors I analyse, to be NGOs, as they are non-governmental and to a larger or smaller extent organised. Thus, for the sake of clarity, I refer in this chapter to 'typical' NGOs as defined above, but also to associations, which includes the full range of formal and informal civil society groups, including the 'typical' NGOs. I use the term NGOs (without the qualifying 'typical') whenever this distinction is of secondary importance. 


\section{Informal groups, movements, zero-budget initiatives}

To register an NGO or in fact an 'association' or 'association of citizens', since 'NGO' is not a legal term in Bosnia-Herzegovina or Serbia, takes money, time and effort. The advantage of registering is that a registered association is a legal entity and, among other things, can receive donations or conduct business to raise funds for its activities and initiatives. However, many groups see no need for such benefits and refrain from registering, either not to waste time and money on what they perceive as unnecessary, or in a conscious act of disengagement with the government's bureaucratic structures. Such groups tend to operate without money or rely on small donations of those involved when there is a need to pay for something. For instance, group members make donations to rent a hall for activities or to buy audio equipment (Interviews \#21, August 2010, and \# 47, January 2011, in Novi Sad). In some cases they arrange in-kind donations.

It would be wrong, however, to think of such groups as always small and insignificant. A good example of such an unregistered, yet significant, initiative (or movement) is Novi Sad's Inicijativa za Drustveni Centar (Initiative for the Social Centre). The initiative, calling itself'social movement' (Društveni Centar n.d.), was formed by 'associations of citizens [including 'typical' NGOs], informal groups and prominent individuals, active in the field of creativity, education, humanitarian work, environmental protection, sustainable development, activism, working with children, youth, persons with disabilities, Roma and other sensitive groups' (ibid.). Their idea was to transform the old abandoned building of an army barracks, $7,293 \mathrm{~m}^{2}$ in size and close to Novi Sad's city centre, into a social centre, a space that would 'enable anyone who engages in activities of significance for society, to accomplish his/her ideas and projects' (ibid.). In practice, this would mean that, for instance, 'Ogledalo', an independent theatre which in over 20 years of its history never had its own space for rehearsals and performances, could finally find such a space in the barracks' many empty rooms.

I first learned about the initiative in mid-November $201 \mathrm{I}$, when a professionally made film (Gmizić et al. 2011), nearly half an hour long, was posted on YouTube, and promoted through Facebook. In the film, leaders of various associations, along with some internationally known Novi Sad 
artists and academics, spoke, mostly from within the barracks, about the great potential of the place. Their contributions were interspersed with shots from former military objects converted into social centres in Slovenia (Metelkova in Ljubljana) and Croatia (Rojc in Pula).

About one month later, on 22 December 2011, around roo people gathered outside the barracks, listened to a couple of short speeches (interpreted into sign language) and then entered the place in what they have called 'illegal but legitimate' action. Armed with brooms and spades they instantly started cleaning the barracks. Soon afterwards an intensive programme of events started. These included crafts workshops, lectures, discussions, film screenings, exhibitions, fencing classes for children and adults, fitness classes, regular vegetarian and non-vegetarian meals cooked by volunteers, dancing parties and late evening concerts among other events. Everything was free to attend and only symbolic donations were encouraged in exchange for meals. At the same time thoughtful organisation and some fundraising were evident. For instance, soon after the opening, two serviced mobile toilets appeared on the site. Such amenities cannot be funded by small donations and must have been provided as an in-kind donation by the enterprise managing these toilets. There were additional signs of professionalism, efficiency and engagement on the part of those involved in Drustveni Centar: excellent media coverage, a professional website, a power generator that allowed events after sunset, and regular publically-announced letters of support from associations and other institutions in Serbia and other post-Yugoslav countries. The occupation of the barracks, and the intensive programme of events that came with it, lasted 22 days, until 13 January 2012 , when the activists were expelled from the buildings by military personnel. However, negotiations with the local government and the engagement of many of the activists lasted much longer.

The initiative could have registered and acted as an NGO, but those who formed it decided not to register, despite the suggestion of Novi Sad city council that this would ease the negotiations between the Initiative and the city authorities. In the eyes of people engaged in the initiative, keeping away from the government-operated register made them even 
more non-governmental and confirmed their role as a civil society actor. ${ }^{5}$ At the same time the initiative was well organised and gathered an impressive number of supporters. According to my interviewee, the initiative was empowered by the work of about 40 'active, loyal and persistent' individuals, who between mid-December 201 I and 24 January 20I2, when the interview took place, 'gave Ioo\% of [their] time'. It also had the support and involvement of several hundred more people who, informed through the e-mailing list, would come to participate in meetings and activities (interview \#53, January 2012, Novi Sad), and of several thousand 'friends' with the initiative on Facebook (4869 on Is June 2013).

The opportunities for active citizenship that Drustveni Centar created were at least of two types. First of all, the people who were engaged in the Initiative made a very active and strong stand on how they wanted the cultural landscape of their city to look like. They wanted change and they worked towards this change, with their words, hands and brooms. But also, those engaged created a certain 'alternative reality' in a broader sense - one based on 'building bridges'. A reality in which all generations cooperated for common good, in which speeches were interpreted into sign language, in which both vegetarians and meat-eaters were satisfied and in which everyone felt that their voice counted and that their contribution was important. Paraphrasing Goldfarb: they acted as if they lived in an equal society, hoping that an equal society will result.

A different example of an active, well organised group which is unregistered and operates without budget is Novi Sad's FreeTeam Pokret ('FreeTeam Movement'). FreeTeam regularly organises not only weekly Free Hugs but also Free Salsa, Free Yoga and Free Film Screenings. While this does not sound particularly serious, projects like Free Hugs should probably not be seen as insignificant in a post-war region where reconciliation and the rebuilding of trust are still needed. Also organising Free Film Screenings

5 Informal communication with people involved in the Initiative, December 20II January 2012, Novi Sad. This indicates that these activists understood civil society to be most of all the counter-balance to the state, as according to Gramsci (2007). 
can be seen as a manifestation of active citizenship. In 20 ro neither Mostar nor Novi Sad had cinemas. In Mostar the reason was clear - it could not be decided on which side of the city the cinema should stand. In Novi Sad, copyright piracy was usually blamed, yet some of my interviewees believed that the lack of a cinema was also linked to local politics (interviews \# I8, August 2010, and \#35, October 2010, in Novi Sad).

\section{Facebook and other online communities}

Many NGOs use Facebook as a tool. Taking into consideration that 'everyone has it', it is excellent for communication and for spreading news about new events. But at the same time Facebook has proved to be a useful path for initiatives that only later, after a successful start-up as a Facebook group, transformed themselves into real life projects. This was the case of MOSTIMUN - Mostar International Model UN - supposedly the first ever joint initiative of students from both of Mostar's universities (the Bosniak Džemal Bijedić University and the Croatian Sveučilište). In this city, divided by invisible barriers along ethnic lines, Facebook appeared to be a safe space to meet and plan a joint event. Online meetings soon became real ones, bringing together not only foreign participants but also young Mostarians from both sides of the Bulevar.

While some of the events started on Facebook later led to establishing NGOs, others have remained in the form of on-line communities. This does not mean that their activities are less 'real'. Actually some of Mostar's and Novi Sad's Facebook groups have a much larger 'membership' than many of these cities' NGOs and some organise events and activities on a regular basis. One example of such Facebook group can be Novosadska Kritična masa (Novi Sad Critical Mass) - a community group of over 5,000 members which is the main forum for the organisation of monthly cycling rides, many of which are attended by several hundred people. At the same time these groups do remain 'virtual' - they have no employees, no running costs, have very horizontal (if any) leadership structures, are easily accessible, can easily appear, and equally easily disappear. However, their 
role as counter-balance to the state or as places of encounter should not be ignored. Similar roles are played by some (but by no means all) mailing lists and other mediums facilitating online communication.

\section{Religious organisations}

Religious organisations are often omitted in research on the region's civil societies. This is understandable as including religion and its institutions in a research project always brings in a whole new range of problems and questions and this is even more the case in Bosnia-Herzegovina and Serbia where religion is considered the determinant of ethnic belonging.

The questionnaire survey which I conducted showed that the world of the religious on the one hand, and of those engaged in all other associations on the other, are quite separate, and/or that religion is a taboo among people engaged in the work of most associations. While only 15.3 per cent of my respondents clearly stated adhering to one of the region's traditional religions, many others did not reply or provided evasive answers, e.g. 'believer' or 'liberal'. What is more, of the I3I respondents to my survey whom I have reached through a range of channels, only two admitted to belonging to a religious organisation.

However, through interviews I discovered that in fact many religious organisations interact with other civil society actors, including 'typical' NGOs. This happens in several ways. First, many religious organisations, especially multi-confessional or protestant, are in their nature and programming very similar to (non-religious) NGOs: they have leadership emergent from, or in another way close to the membership base, they have budgets nourished by sponsors and/or membership fees, they provide for the integration, education (in this case usually religious) and/or recreation of the members, etc. ${ }^{6}$ Second, many religious organisations are involved in

6 It was my observation (confirmed in interview \#20, August 2010, in Novi Sad) that the choice of programmes and the way that Protestant and ecumenical organisations operate is closer to that of NGOs than of Orthodox or Catholic groups, and that 
humanitarian activities and for specific programmes they liaise with NGOs to use their expertise and field-related-experience. Third, religious movements - like, for example, Taizé ${ }^{7}$ - are at the same time an alternative and a 'springboard' for engagement in activities of NGOs. They are an alternative because even though they are not considered to be NGOs, they meet the same needs for the individual: a chance to meet interesting people, to travel together, to be involved in something 'big' and so forth. Therefore they are able to attract those who are intimidated by NGOs which are often criticised, or who simply feel better in a large and well established community in which they can remain as passive and as anonymous as they wish. Conversely, these movements can also sometimes be a 'launching pad' since through their meetings or pilgrimages, young people get accustomed to being in a group, engaging in logistical planning, etc., and in this way develop confidence in due course to take on NGO initiatives. By means of training and activities with a 'tag' of a religious group participants become active citizens and in many cases this acquired activism remains by no means confined to their religious community.

this is mostly because of their more horizontal structures. The same idea was referred to by Putnam who wrote that 'all religious groups blend hierarchy and equality, but networks within Protestant congregations are traditionally thought to be more horizontal than networks in the Catholic Church' (Putnam 1992, 173).

7 According to its official website ' $[t]$ oday, the Taizé Community is made up of over a hundred brothers, Catholics and from various Protestant backgrounds, coming from around thirty nations. By its very existence, the community is a "parable of community" that wants its life to be a sign of reconciliation between divided Christians and between separated peoples.' (Taizé n.d.) While the very Community is relatively small, thousands of young people participate regularly in pilgrimages to the French village of Taizé where the monastery is located or to other international encounters organised by the Community, meet regularly to sing songs from these pilgrimages, etc. Thus, one can talk about the 'Taizé movement' consisting of people engaged in all these activities, those who organise local meetings, etc. 


\section{Student Unions}

Student Unions, both in Mostar and Novi Sad, are bodies traditionally attached to universities. Nevertheless, their activities and scope of work are often similar to those of NGOs and other associations. Furthermore, it seems that they have always been easily accessible (at least for students) and for this reason several of the leaders of associations in Mostar and Novi Sad mentioned activism in student unions as their first leadership experience (interviews \#19 and \#23, August 2010, and \#34, October 2010, in Novi Sad). In Mostar, where the two universities are among the most visible manifestations of division between the different ethnicities, student unions and their activities appear to play an important role in the process of (re)building trust between young people of these different ethnic groups. For example, Bosniak and Croat, the languages of the two universities and according to many, the main reason for ethnically-divided education in Mostar (Hromadžić 2008, 556-558), become a shared 'nas' (our [language]) when students from the two unions get together to put on a public speaking competition (Interview \#13, April 2010, in Mostar).

\section{Associations established in the time of communist Yugoslavia}

Professional, interest-based and charitable organisations, such as associations of poets, journalists, fishermen and dog breeders, chess clubs, or associations of people with disabilities, existed in the times of communist Yugoslavia and many of them still operate. However, they are rarely considered in the research on Western Balkan civil societies. Probably one of the main reasons for that is that their status as civil society actors can be easily questioned. In the context of research which is trying to establish links between the work of civil society actors and processes of reconciliation and democratisation, associations of dog breeders or cyclists do not seem worthy of serious consideration. However, one of the points which this chapter is trying to demonstrate is that such associations should not be seen as automatically less significant for the sought after processes of 'bridge building' than the 'typical' NGOs. 
A mountaineering club in Mostar, in whose activities I had a chance to participate, is a good example. The club does not resemble 'typical' NGOs: it is not a think-tank, not an advocacy organisation, and it would be difficult to trace any conscious attempts on the part of its leadership to build any kind of bridges. Still, the mountain hikes that it organises are a unique phenomenon in Mostar and it can be argued that they contribute to building numerous 'bridges'. These hikes regularly bring together Bosniaks and Croats, and also young and old, locals and foreigners, and people of different social strata. The contrast between the cheap flip-flops and old T-shirts of some participants, and the expensive mountain gear of others, attracts the attention of people like myself but does not seem to be a serious problem for those regularly taking part in the hikes. Without declaring any pro-diversity agenda the club and the participants of its hikes actively create a new reality. It is a 'small thing' - micro-politics - but an important one at that.

\section{Conclusions}

This chapter examined how citizens of two post-Yugoslav cities actively practise their citizenship by engaging in work of local civil society. It argued that it is worthwhile to consider this civil society in its broad sense: as comprised not only of 'Western style,' 'typical' NGOs but also of local professional, interest, sport and charitable associations, informal groups and movements, online groups, student unions and religious associations. These actors dramatically vary in their engagement, or lack of it, in (traditionally understood) politics and in the type of opportunities they create. Their commonality however is that they intend to change today's, often conflicted, reality.

These actors, these 'institutions' of broadly understood civil society, provide for what we could see as acts of citizenship (Isin 2008). They form a setting for the 'routines, rituals, customs, norms and habits of the everyday 
through which subjects become citizens' (Isin 2008, I7), a setting for 'cultivating citizenship' (ibid.) and for 'enacting' it. A setting in which 'subjects [are] becoming activist citizens through scenes created' (ibid., 38 ). In which acts may turn into actions. Many of them also allow for practices of 'vernacular cosmopolitanism' (Bhabha 1996), in its broad sense, opening to human other and negotiating common aims across (not only ethnic) difference.

Theories of micro-politics and of 'everyday peace' direct us into recognising the value of seemingly unimportant actors and practices which, little by little and often in a very unpronounced fashion, contribute to changes on a larger scale. Time will show whether this is the case with civil society (in its broad sense) in the post-war Western Balkans and whether its 'micro-efforts' will contribute to serious change. Meanwhile, however, we may appreciate that there are many citizens who decide to be active citizens, to enact their citizenship, and who, through everyday involvement in their associations, do create certain new realities.

\section{Bibliography}

Andrić, I. (1977). The Bridge on the Drina. Chicago: University of Chicago Press. Beauregard, R. and S. Body-Gendrot (1999). The Urban Moment: Cosmopolitan Essays on the Late-2oth-Century City. Thousand Oaks, CA: Sage.

Bhabha, H. (1996). 'Unsatisfied: Notes on Vernacular Cosmopolitanism.' In Laura Garcia-Morena and Peter C. Pfeifer (eds), Text and Nation: Cross-Disciplinary Essays on Cultural and National Identities. Columbia, SC: Camden House, pp. $191-207$.

Bicic, E. (1993). 'Bombe Sulla Storia: Crolla Il Ponte Di Mostar. E a Sarajevo Una Granata Fa Strage Di Bimbi.' Corriere della Sera.

Bieber, F. and J. Winterhagen (2006). 'Ethnic Violence in Vojvodina: Glitch or Harbinger of Conflicts to Come?' http://www.ecmi.de/uploads/media/working paper_27.pdf (April 2, 2013).

Binnie, J., Holloway, J., Millington, S. and C. Young (2006). Cosmopolitan Urbanism. London and New York: Routledge. 
Dević, A. (2003). 'Guarding and Guiding Regionalism and Interculturalism: Civil Society and Non-Governmental Organizations in Vojvodina.' http://www. watsoninstitute.org/muabet/docs/Ana_Devic.doc (May 17, 2013).

Društveni C. (2013). 'Introducing the Initiative for Independent Social Centre.' http:// drustvenicentar.org/index.php?option $=$ com_content\&view $=$ article\&id $=164$ (June I3, 2013).

Fagan, A. (2010). Europe's Balkan Dilemma: Paths to Civil Society or State-Building? London: I.B. Tauris.

Fuller, S., Kershaw, P. and J. Pulkingham (2008). 'Constructing "Active Citizenship": Single Mothers, Welfare, and the Logics of Voluntarism.' Citizenship Studies $12(2):$ 157-176.

Mac Ginty, R. (2013). 'Indicators+: A Proposal for Everyday Peace Indicators.' Evaluation and program planning 36(I): 56-63. http://www.ncbi.nlm.nih.gov/ pubmed/22868180 (October 19, 2014).

Gmizić, D., Kovacs, S., Skutelis, O., Polgar, C., Rašković, V., Dimitrovska, D. and A. Bede (20II). Otvorene Kasarne. YouTube. https://www.youtube.com/ watch?v=UqQyI If AuU (June 17, 2013).

Goldfarb, J.C. (1980). The Persistence of Freedom: The Sociological Implications of Polish Student Theater. Boulder, CO: Westview Press.

Goldfarb, J.C. (2006). The Politics of Small Things: The Power of the Powerless in Dark Times. Chicago: University of Chicago Press.

Goldfarb, J.C. (2008). 'The Sociology of Micro-Politics: An Examination of a Neglected Field of Political Action in the Middle East and Beyond.' Sociology Compass 2(6): 1816-1832.

Goldstein, P. (2015). 'Grassroots Narratives and Practices of Diversity in Mostar and Novi Sad.' In T. Matejskova and M. Antonsich (eds), Governing through Diversity: Migration Societies in Post-Multiculturalist Times. London: Palgrave Macmillan, 104-I24.

Goldsworthy, V. (2002). 'Invention and In(ter)vention: The Rhetoric of Balkanization.' In D. Bjelić and O. Savić (eds), Balkan as Metaphor: Between Globalization and Fragmentation. Cambridge, MA, London, England: The MIT Press, 25-38. Gramsci, A. (2007). Prison Notebooks. New York: Columbia University Press.

Gunzburger Makaš, E. (200I). 'Representing Multinational Bosnian Identity: The Bridge Metaphor and Mostar's Stari Most.' http://www.academia.edu/2211315/ Bridge_Metaphor_and_Mostars_Stari_Most_Cornell_U_Ithaca_200I_ (August 2, 2013).

Hromadžić, A. (2008). 'Discourses of Integration and Practices of Reunification at the Mostar Gymnasium, Bosnia and Herzegovina.' Comparative Education Review 52(4): 54I-563. 
Isin, E.F. (2008). 'Theorizing Acts of Citizenship.' In E.F. Isin and G.M. Nielsen (eds), Acts of Citizenship. London: Palgrave Macmillan, $15-43$.

Jansen, S. (2005). 'Who's Afraid of White Socks? Towards a Critical Understanding of Post-Yugoslav Urban Self-Perceptions.' Ethnologia Balkanica (9): I5I-167.

Kearns, A. (1995). 'Active Citizenship and Local Governance: Political and Geographical Dimensions.' Political Geography i4(2): 155-175.

Kostovicova, D. and V. Bojičić-Dželilović (2013). 'Introduction: Civil Society and Multiple Transitions - Meanings, Actors and Effects.' In V. Bojičić-Dželilović, J. Ker-Lindsay, and D. Kostovicova (eds), Civil Society and Transitions in the Western Balkans. London: Palgrave Macmillan, I-28.

Marinetto, M. (2003). 'Who Wants to Be an Active Citizen?: The Politics and Practice of Community Involvement.' Sociology 37(I): 103-120. http://soc.sagepub.com/ cgi/doi/10.1177/0038038503037001390 (October 31, 2014).

Mercer, C. (2002). 'NGOs, Civil Society and Democratization: A Critical Review of the Literature.' Progress in Development Studies 2(I): 5-22.

Nava, M. (2002). 'Cosmopolitan Modernity: Everyday Imaginaries and the Register of Difference.' 19: 8I-99. http://hdl.handle.net/10552/134.

Piekut, A., Rees, P., Valentine, G. and M. Kupiszewski (2012). 'Multidimensional Diversity in Two European Cities: Thinking beyond Ethnicity.' Environment and Planning A 44(12): 2988-3009.

Putnam, R.D. (1992). Making Democracy Work: Civic Traditions in Modern Italy. Princeton: Princeton University Press.

Rumiz, P. (201I). Maschere per Un Massacro. Quello Che Non Abbiamo Voluto Sapere Della Guerra in Jugoslavia. Milano: Feltrinelli Editore.

Sardelić, J. (2013). "Communist Zombies": Notes on Active Citizenship in Slovenia.' Citizenship in Southeast Europe. http://www.citsee.eu/blog/"communistzombies"-notes-active-citizenship-slovenia (October 24, 2014).

Štiks, I. and S. Horvat (2014). 'The New Balkan Revolts: From Protests to Plenums, and Beyond.' openDemocracy. https://www.opendemocracy.net/can-europemake-it/igor-štiks-srećko-horvat/new-balkan-revolts-from-protests-to-plenumsand-beyond (October 24, 2014).

Stubbs, P. (1999). Displaced Promises: Forced Migration, Refuge and Return in Croatia and Bosnia-Herzegovina. Uppsala: Life \& Peace Institute.

Sudetic, C. (1993). 'Mostar’s Old Bridge Battered to Death.' New York Times.

Taizé.'A “Parable ofCommunity." http://www.taize.fr/en_article6525.html (July 8, 2013). Tocqueville, A. de (1956). Democracy in America. New York: New American Library. Todorova, M. (1997). Imagining the Balkans. New York and Oxford: Oxford University Press.

Williams, C.J. (1993). 'Bosnia’s Hopes Fall With Historic Bridge in Mostar.' Los Angeles Times. 
